\title{
Mapping of nutrients status by geographic information system (GIS) in Navagarh block under Janjgir district in Chhattisgarh
}

DEEPIKADEVDAS, L. K. SRIVASTAVA AND V.N. MISHRA

Received : 29.01.2016; Revised : 01.04.2016; Accepted : 27.04.2016

MEMBERS OF RESEARCH FORUM:

Corresponding author : DEEPIKA DEVDAS, Department of Soil Science and Agricultural Chemistry, Indira Gandhi Krishi Vishwavidyalaya,, RAIPUR (C.G.) INDIA

Email: deeps.devdas@gmail.com

Co-authors :

L.K. SRIVASTAVA AND V.N. MISHRA,

Department of Soil Science and Agricultural Chemistry, Indira Gandhi Krishi Vishwavidyalaya, RAIPUR (C.G.) INDIA

\section{Summary}

A study was conducted to assess available nutrient status of soils of Navagarh block in Chhattisgarh by GIS technique. Grid based surface $(0-15 \mathrm{~cm})$ drawn from the farmers' fields were analysed for their fertility status and mapped by geographic information system (GIS) technique from 125 villages of Navagarh block.The soil samples were analyzed for $\mathrm{pH}, \mathrm{EC}$, $\mathrm{OC}, \mathrm{N}, \mathrm{P}, \mathrm{K}, \mathrm{Fe}, \mathrm{Mn}, \mathrm{Cu}, \mathrm{Zn}$. The soil $\mathrm{pH}$ varied from 4.8 to 8.0 (mean 5.93) and indicated that soils were found to be moderately acidic to slightly alkaline in reaction. The electrical conductivity of soil water suspension ranged from 0.04 to $0.98 \mathrm{dS} \mathrm{m}^{-1}$ with a mean value of $0.20 \mathrm{dS} \mathrm{m}^{-1}$ and all soil samples under normal range $\left(<1.0 \mathrm{dS} \mathrm{m}^{-1}\right)$. The mean value of organic carbon was 0.55 per cent and about 90 per cent soils of this block comes under medium fertility group. The soils were low in available $\mathrm{N}$ content. It ranged from 87 to $399 \mathrm{~kg} \mathrm{ha}^{-1}$ with an average of $258 \mathrm{~kg} \mathrm{ha}^{-1}$. The status of available phosphorus varied from 1.52 to $29.33 \mathrm{~kg}$ ha ${ }^{1}$ with a mean value of $12.88 \mathrm{~kg} \mathrm{ha}^{-1}$. The 96.82 per cent village soil samples from the study area can be classified as low fertility class. Nutrient index values were in low fertility class except 8 villages for $\mathrm{N}$ and 44 villages for $\mathrm{P}$ comes under medium nutrient index value. The available potassium varied from 88 to $503 \mathrm{~kg} \mathrm{ha}^{-1}$ with a mean value of $279 \mathrm{~kg} \mathrm{ha}^{-1}$. The more than 90 per cent soil samples were classified as medium to high fertility class. The available iron, manganese, copper and zinc content ranged from 0.44 to $91.6 \mathrm{mg} \mathrm{kg}^{-1}$ (mean $25.47 \mathrm{mg} \mathrm{kg}^{-1}$ ), 0.32 to $84.4 \mathrm{mg} \mathrm{kg}^{-1}$ (mean $29.90 \mathrm{mg} \mathrm{kg}^{-1}$ ) and 0.16 to $28.1 \mathrm{mg} \mathrm{kg}^{-1}$ (mean $2.56 \mathrm{mg} \mathrm{kg}^{-1}$ ), 0.02 to $10.84 \mathrm{mg} \mathrm{kg}^{-1}$ (mean $1.61 \mathrm{mg} \mathrm{kg}^{-1}$ ), respectively in soil of Navagarh block. Most of soil samples were found in sufficient levels of $\mathrm{Fe}, \mathrm{Mn}$ and $\mathrm{Cu}$ but 32.21 per cent soil samples were deficient in $\mathrm{Zn}$ content. Soil nutrient index of overall soils group were found in low fertility class of nitrogen and phosphorus and high fertility class with respect to potassium. Most of the area of Navagarh block was covered by LLM, LLH and LMH categories.

Key words : Geographic information system, Global positioning system, Nutrient mapping, Soil fertility status

How to cite this article : Devdas, Deepika, Srivastava, L.K. and Mishra, V.N. (2016).Mapping of nutrients status by geographic information system (GIS) in Navagarh block under Janjgir district in Chhattisgarh. Asian J. Soil Sci., 11 (1) : 103-109 : DOI : 10.15740/HAS/AJSS/11.1/103-109. 